\title{
Analysis for Theory of Integrated Resource Strategic Planning Based of Power Balance between Supply and Demand
}

\author{
Junjie Kang ${ }^{1}$ \& Jinghong Zhou ${ }^{2}$ \\ ${ }^{1}$ School of Economics and Management, North China Electric Power University, Beijing, China \\ ${ }^{2}$ Jilin Electric Power Research Institute, Changchun, China \\ Correspondence: Junjie Kang, School of Economics and Management, North China Electric Power University, \\ Beijing 102206, China. E-mail: hbdlljp@163.com
}

\author{
Received: August 28, 2012 Accepted: September 10, $2012 \quad$ Online Published: November 30, 2012 \\ doi:10.5539/ass.v8n15p136 URL: http://dx.doi.org/10.5539/ass.v8n15p136
}

\begin{abstract}
First this paper analyzes China electric power market price regulation and power supply enterprises' decision-making behaviors, and then carries on comparative analysis about integrated resource planning theory and integrated resource strategic thought under demand balance angle. The results show that integrated resource planning can reduce the power demand and optimize resource allocation, but integrated resource strategic planning under the demand side management has better effect, also can realize the whole society power resources optimal allocation.
\end{abstract}

Keywords: demand side management, integrated resource planning, integrated resource strategic planning, supply and demand balance

\section{Introduction}

In recent years, the rapid growth of China's energy consumption has caused seriously ecological and environmental problems. Therefore, the country has taken all kinds of relevant measures to ease the pressure on ecological environment; In this case, only considering the power supply side of the traditional electric power planning is difficult to meet the need of economic and social sustainable development. Integrated resource planning carries out development and extension about the concept of traditional electric power planning, brings power saving into the power overall planning as a kind of resource.

But with China's power system reform deepening, achieving "plant-network apart", power generation enterprises and grid enterprises are no longer have unified planning and management function about generation, transport, distribution and use. In actual operation, the power generation enterprises and power grid enterprises will pursue their own interests maximization as the management goal, no longer consider the whole society overall benefit, Also can't do integrated resource planning, therefore, integrated resource strategic planning from the national level is needed. This paper carries on the analysis on Pareto optimality of integrated resource strategy thought from the point of electric power supply and demand balance.

\section{Electricity Price Regulation and Electric Power Enterprises Behaviors Analysis}

\subsection{Electricity Price Regulation}

At present, electric power enterprises in most areas are in natural monopoly position, therefore, if there is no regulation, electric power enterprise in monopoly market structure will make the decision of achieving their own profit maximum. According to economics principles, the condition of enterprises realizing the profit maximum is marginal revenue (MR) equal to marginal cost (MC).

$$
M R=\frac{\Delta R}{\Delta Q}=\frac{\Delta(p \cdot Q)}{\Delta Q}=p+Q \frac{\Delta P}{\Delta Q}
$$

According to the price elasticity of demand (Ed) definition

$$
E_{d}=\frac{p}{Q} \cdot \frac{\Delta Q}{\Delta P}
$$

There is 


$$
M R=P+P\left(\frac{Q}{P} \cdot \frac{\Delta P}{\Delta Q}\right)=p+p \cdot\left(\frac{1}{E_{d}}\right)
$$

When $\mathrm{MR}=\mathrm{MC}$, we can get

$$
P=\frac{M C}{1+\left(1 / E_{d}\right)}
$$

Because the power demand elasticity is generally small negative value, according the formula (3), electric power enterprises formulate the electricity price based on their own benefit maximum principle, which will be far more than the marginal cost. As shown in figure 1, in monopoly situation, electric power enterprises price for Pm which is far higher than the marginal cost pricing Pc, the result reflected in the reality is high electricity price and little electricity supply (Herter K, 2007).

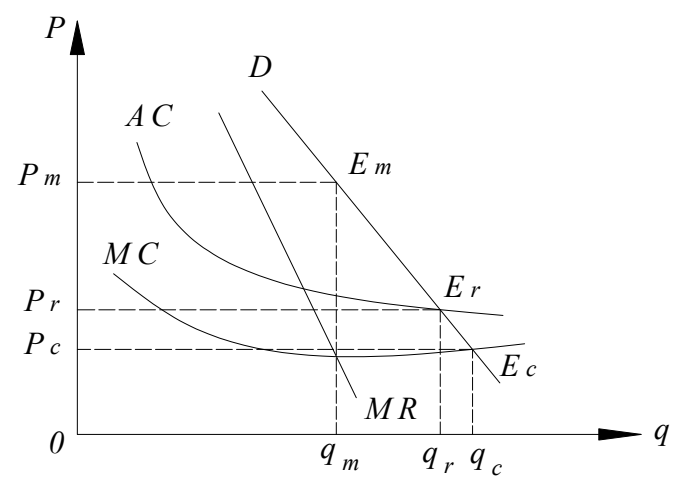

Figure 1. Electricity price regulation of electric power enterprises

Under perfect competition market condition, the commodity price of the goods is equal to marginal revenue and marginal cost, namely: $P=M R=M C$. According to welfare economics principle, in perfect competition economy, commodity equilibrium price has realized Pareto optimality condition in both production and exchange, therefore, it is generally thought that market equilibrium price in perfect competition economy is the most efficient. Monopoly enterprises usually make commodity prices higher than the marginal cost, to gain monopoly profits, which are usually considered unfair, at the same time, monopoly also results in the resource allocation lack of efficiency. For monopoly power measurement, economics usually uses Lerner index (L) to determine, namely

$$
L=\frac{P-M C}{p}=-\frac{1}{E_{d}}
$$

From the above formula, we can see that Lerner index is the reciprocal of electric power demand elasticity. Because power demand has large rigidness, and power demand elasticity is smaller, so, the electric power enterprises' Lerner index is very big, which shows that the electric power enterprises' monopoly power is large. Therefore, governments all over the world generally regulate the electric power enterprises, in order to make the production of electric power industry much more economically efficient (Arif S, Malik, Cecilio U \& Sumaoy, 2003).

\subsection{The Electric Power Enterprises' Behavior Analysis under Power Demand Change}

Since power demand is changeable in the short term, therefore, it is necessary to analyze electric power enterprises' behaviors under the condition of short-term power demand change.Here with certain electric power enterprises' production cost and regulation price, analyzes electric power demand changes, electric power enterprises' economic profits and the possible measures electric power enterprises may take when electric power demand changes, as figure 2 shows. 


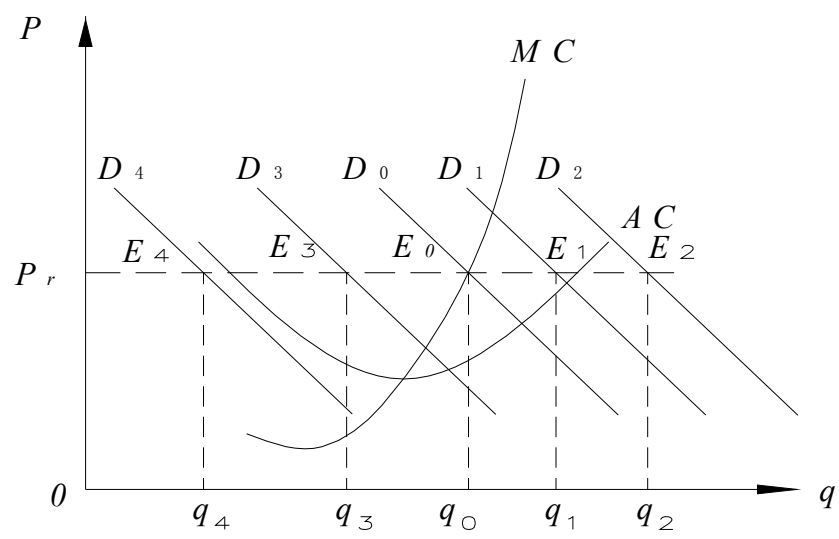

Figure 2. Analysis of electric power enterprises' behaviors under changeable demands

When electric power demand is less than the best decision output q0 (E3 point in figure 2) of electric power enterprises, the electric power enterprises' profits are less than profit level of optimal output, at this time, electric power enterprises will promote power consumption through all sorts of methods, in order to realize electric power enterprises' profits maximum. Especially, if the electric power demand is less than the electric quantity determined by electric power enterprises' average cost and regulation price (E4 point in figure 2), then electric power enterprises' average cost is higher than regulation price, electric power enterprises will be in the economic losses state, on one hand, electric power enterprises will encourage power consumption through various means, on the other hand, they will shrink power supply scale. When electricity demand is equal to electric power enterprises' best decision output (E0 point in figure 2), electric power enterprises' profit level achieves maximum, generally will not take any measures. When electric power demand is greater than the best decision output q0 (E1 point in figure 2) of electric power enterprises, electric power enterprises' profits are less than profit level of optimal output, at this time, electric power enterprises will reduce power consumption through all sorts of methods, while the cost of decreasing electricity consumption is less than the profits which electric power enterprises achieve, because of reduced electricity demand, electric power enterprises will actively implement electricity demand side management measures, so as to enlarge enterprise profit level. Especially, if the electric power demand is greater than the electric quantity determined by the electric power enterprises' average cost and regulation price (E2 point in figure 2), then the electric power enterprises' average cost is higher than the regulation price, electric power enterprises will be in the economic losses state, on one hand, the electric power enterprises will reduce power consumption through various means, and take more powerful power demand side management measures, on the other hand, they will expand power supply scale, in order to reduce electric power enterprises' average production cost.

\section{Integrated Resource Strategic Planning Theory Contrast and Analysis}

\subsection{Electric Power Supply and Demand Balance under Traditional Electric Power Planning Thoughts}

Under the traditional electric power planning thoughts, electric power enterprises meet electricity demand only on power source construction, electric power enterprises form power supply through planned investment construction, according to the expected future power demand. From the above analysis, we can conclude that power supply will change only in the long term, and the overall performance of power supply change is power supply curve shifting towards right, at the same time, expanding power supply limit correspondingly. Also in the long term, electric power demand will increase for social and economic development level, and the increase of power supply is to meet this demand to form new supply and demand balance. 


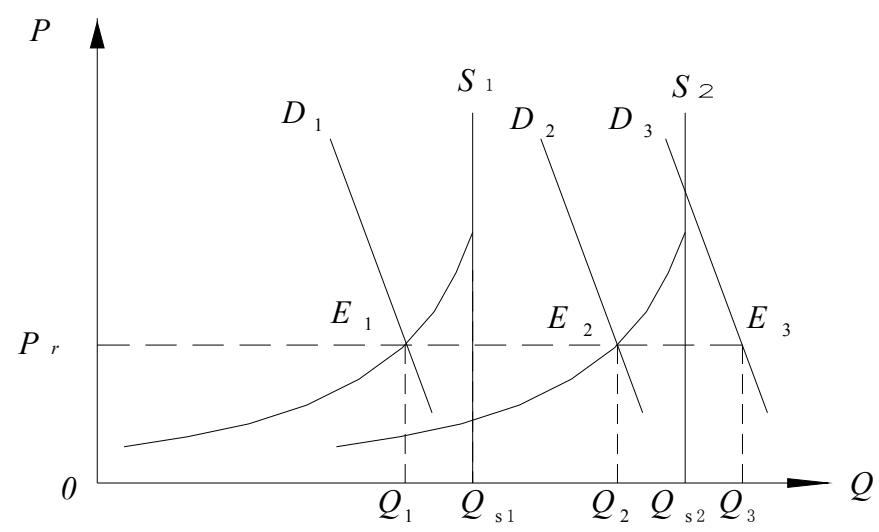

Figure 3. Balance of electric power supply and demand under traditional power planning thoughts with electricity price regulation

As shown in figure 3 , in the electricity price regulation cases (Pr), the supply curve (S1) and the demand curve (D1) intersect at equilibrium point E1, power supply and demand balance electricity quantity is Q1,short-term supply limit is Qs1. Electric power department forecasts power demand Q2 according to its own forecasting results about electric power demand at next phase, then organizes to expand power generation capacity through the expected results, so power supply curve is $\mathrm{S} 2$ at the second phase, short-term supply limit expands to Qs2. If electric power demand curve is like expected indeed, power supply and demand regain balance at point E2, but, if the actual power demand is greater than the expected power demand, phenomenon lack of electricity is emerged, now in the electric power demand curve E3, the corresponding demand electricity quantity is Q3, beyond the short-term supply limit Qs2, even if starting all generating sets would be difficult to meet the social electricity demand.

\subsection{Electric Power Supply and Demand Balance under Integrated Resource Planning Theory}

Integrated resource planning ideas realize the balance of electric power supply and demand not only through power source construction, but also through power demand side management. Because the long construction period of expanding power production capacity, power supply exists supply limit in the short term, also power demand has certain rigidness, when electric power department is unable to meet short-term power supply, it reduces power demand from power demand side management to keep electric power supply and demand balance As figure 5-7 shows, in the first period, electric power enterprises predict that electricity consumption at the second phase will reach Q3, on one hand, increase supply limit from QS1 to QS2 through power source construction in supply side, on the other hand, take measures in power demand side to move demand curve from D3 to D2, then the power supply and demand balance electricity quantity at second issue will be Q2, then it satisfies power demand of the whole society within electric power enterprises short-term supply limit.

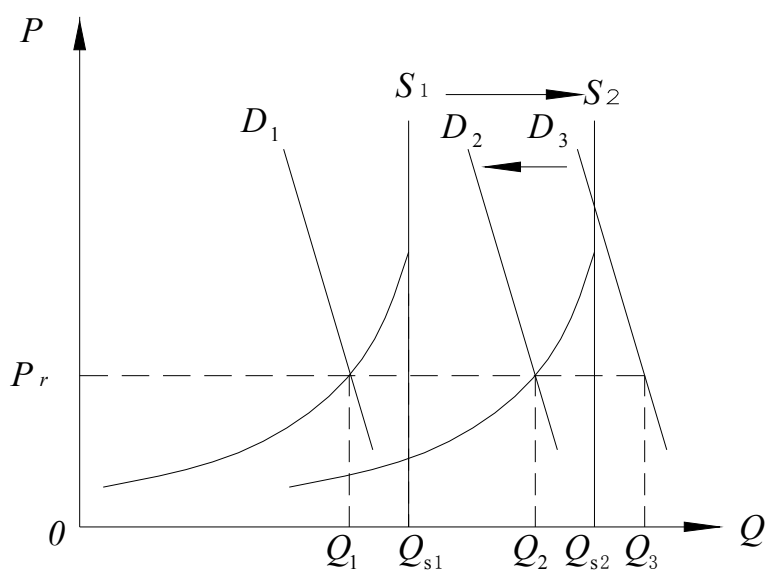

Figure 4. Balance of electric power supply and demand under integrated resource planning 


\subsection{Electric Power Supply and Demand Balance under Integrated Resource Strategic Planning Theory}

In integrated resource planning, main reason of electric power enterprises implementing power demand side management is for the maximization of self-interest. When power demand deviates from the profit maximization decision point, take appropriate measures to reduce power demand. Integrated resource strategic planning is comparing the pros and cons of investing power supply side and power demand side in the height of national strategy, not a simple economic and financial comparison.

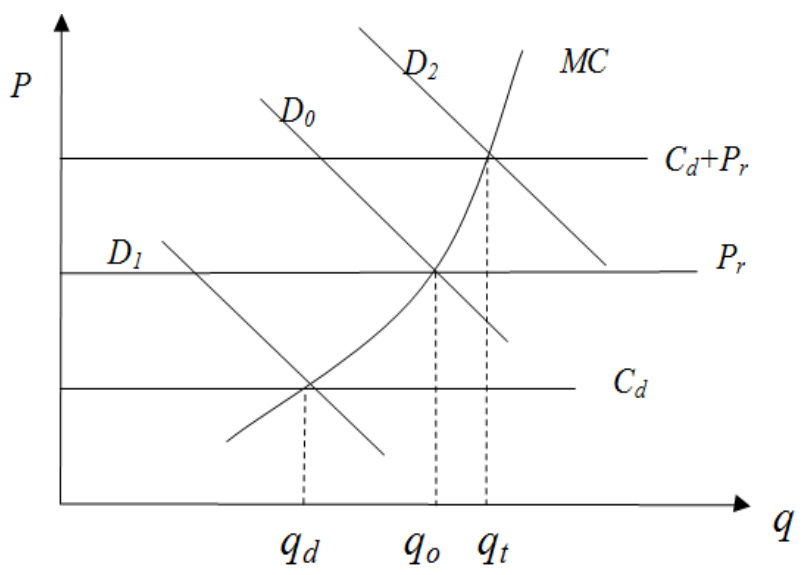

Figure 5. Analysis of Electric Power Enterprises' Behaviors under integrated resource strategic planning

As shown in figure 5, when electric power demand is less than the best decision output q0 of electric power enterprises, electric power enterprises' profit is less than profit level at optimal output, at this moment, electric power enterprises will promote electricity consumption through various methods to realize electric power enterprises' profits maximum, which is the same in both traditional electric power planning angle and integrated resource planning point of view. But from the view of integrated resource strategic planning, when the power demand is greater than qd and less than q0, although at this time the government's regulation electricity price is $\mathrm{Pr}$, which is higher than the marginal cost $\mathrm{MC}$ of electric power enterprises, but from the social point of view, electric power enterprises' marginal cost is more than the marginal cost of power saving $\mathrm{Cd}$, so from the angle of the whole society, we should cut power demand by demand side management, then can realize resource optimal allocation in whole society. When electric power demand is greater than q0, and less than $\mathrm{qt}$, if the electric power enterprises carry out demand side management, then cost is $\mathrm{Cd}$ without any income, so the net income is $\mathrm{Cd}$; but when electric power enterprises maintain to produce, their marginal cost is MC, earnings are Pr, net income is $(\mathrm{MC}-\mathrm{Pr}$ ); Due to $\mathrm{Cd}$ is greater than (MC-Pr), electric power enterprises will choose to maintain production, rather than reduce electric power demand by demand side management; Only when power demand is greater than qt, electric power enterprises will implement demand side management actively based on their own benefit maximization, cut down electricity consumption (Hu, Zhaoguang, Tan, Xiandong \& Yang, Fan, 2010). But from the integrated resource strategic planning point of view, when electric power demand is greater than $\mathrm{q} 0$ and less than qt, the marginal cost of power production is greater than the marginal cost of power saving, so the optimal choice is to reduce power consumption through demand side management, when countries will guide and stimulate power production enterprises to expand and increase demand side management strength, reduce power demand through financial subsidies and tax breaks and preferential measures, in order to realize resource optimal allocation in whole society (Hu, Zhaoguang, Wen, Quan \& Wan, Jianhui, 2010). Integrated resource strategic planning is standing in the point of government to do electric power planning, its basic performance form about electric power supply and demand balance is like figure 4, but the results of two kind thoughts are different. Through the front analysis, we can see that corresponding to the integrated resource planning, integrated resource strategic planning is much more effectual in demand side management. 


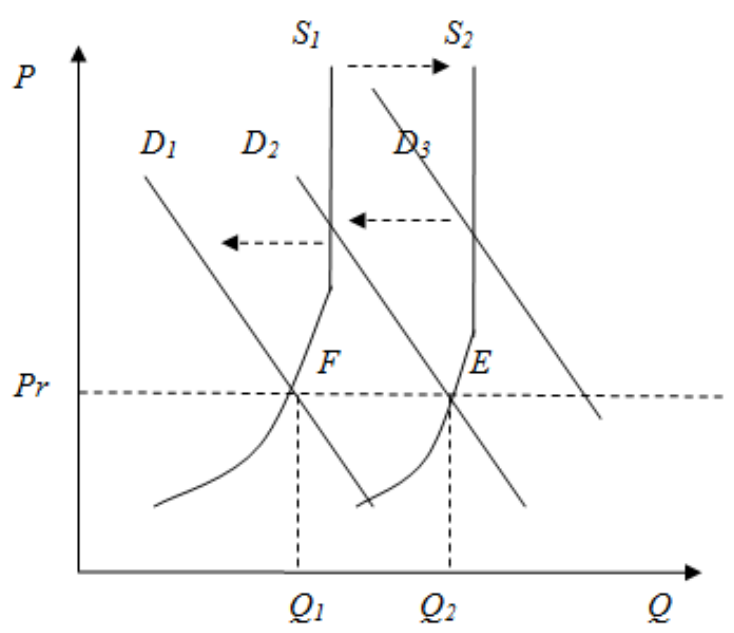

Figure 6. Balance of electric power supply and demand under integrated resource strategic planning

As shown in figure 6, under integrated resource planning thought, when social power demand increases from D1 to D3, on one hand, electric power enterprises can increase power supply, supply curve will move from S1 to right; On the other hand, will reduce electricity demand through demand side management, make the demand curve move to the left, and finally balance at E point. Through the above analysis, we can see that the electric power enterprises realize the profit maximum at $\mathrm{E}$ point. But under integrated resources strategic planning thought, the marginal cost of implementing demand side management at point $\mathrm{E}$ is still less than that of power production, keeping promoting demand side management can still achieve Pareto improvement, so the country will take various measures to stimulate electric power enterprises to continue demand side management, namely, power demand curve D2 will continue to move to the left. The final electricity supply quantity at the supply and demand balance could be less than Q2, and even less than Q1.

\section{Conclusions}

Through the front analysis, we can see that integrated resource planning theory considers the influence of power demand side towards electric power supply and demand, on one hand, it can reduce power supply, on the other hand, it can realize Pareto improvement about resource configuration; but the integrated resources strategic planning can reduce power supply further, realize electric power resources optimal allocation in the whole society, will be able to realize the Pareto optimality. When implementing the integrated resource strategic planning, the country needs to give electric power enterprises internal subsidies and transfer payment, in order to improve the enthusiasm of the demand side management about electric power enterprises (Kang, Junjie, Yan, Jiahai \& Hu, Zhaoguang, 2012).

\section{References}

Malik, A. S., \& Sumaoy, C. U. (2003). A case study of local integrated resource planning. Energy, (28), 711-720. http://dx.doi.org/10.1016/j.enpol.2006.06.019

Herter, K. (2007). Residential implementation of critical-peak pricing of electricity. Energy Policy, (35), 2121-2130.

Hu, Z. G., Tan, X. D., \& Yang, F. (2010). Integrated resource strategic planning: Case study of energy efficiency in the Chinese power sector. Energy Policy, (38), 6391-6397. http://dx.doi.org/10.1016/j.enpol.2010.04.021

Hu, Z. G., Wen, Q., \& Wan, J. H. (2010). Integrated resource strategic planning in China. Energy Policy, (38), 4635-4642. http://dx.doi.org/10.1016/j.enpol.2010.04.019

Kang, J. J., Yan, J. H., \& Hu, Z. G. (2012). Review on wind power development and relevant policies in China during the 11th Five-Year-Plan period. Renewable and Sustainable Energy Reviews, (16), 1907-1915. http://dx.doi.org/10.1016/j.rser.2012.01.031 